\title{
МЕЖДУНАРОДНАЯ ЭКОНОМИКА
}

УДК: 339.972, 338.124.4

JEL: O23, I31, I38

\section{Социально-экономические последствия пандемии COVID-19 в России и странах мира: анализ антикризисных программ, влияние на позицию в международных рейтингах и перспективы восстановления}

\author{
К.X. Зоидов, к.ф-м.н., доцент \\ https://orcid.org/0000-0002-8474-0895; SPIN-код (РИНЦ): 2293-9802 \\ Scopus author ID: 57190430349 \\ e-mail: kobiljonz@mail.ru \\ К.С. Янкаускас, н.с. ИПР РАН \\ https://orcid.org/0000-0003-2380-7088; SPIN-код (РИНЦ): 6937-4745 \\ e-mail: jankauskas.ipr.ras@gmail.com
}

Для цитирования

Зоидов К.Х., Янкаускас К.С. Социально-экономические последствия пандемии COVID-19 в России и странах мира: анализ антикризисных программ, влияние на позицию в международных рейтингах и перспективы восстановления // Проблемы рыночной экономики. 2021. - № 3. - С. 158-178.

DOI: https: //doi.org/10.33051/2500-2325-2021-3-158-178

\begin{abstract}
Аннотация
В статье рассматриваются социально-экономические последствия пандемии коронавируса, такие как рост уровня бедности и социального расслоения. Цель. Выявить и проанализировать социально-экономические последствия пандемии коронавируса в России и других странах мира, меры национальных правительств по борьбе с данными последствиями, а также динамику позиций России в международных экономических рейтингах и наличие или отсутствие взаимосвязи данной динамики с динамикой инвестиций в национальной экономике. Задачи. Анализ показателей бедности и социального расслоения в России и мире в условиях пандемии коронавируса; сравнение антикризисных экономических программ в крупнейших странах мира и России по объему ВВП; изучение методологии наиболее авторитетных международных экономических рейтингов; сравнительный анализ динамики позиций России в международных экономических рейтингах и динамики инвестиций в основной капитал и прямых иностранных инвестиций в Россию. Методология. В ходе исследования применены методы системного анализа, классификации и сравнения, эволюционно-институциональной теории и исторического подхода. Использовались статистические и другие данные Федеральной службы государственной статистики РФ, федеральных органов исполнительной власти РФ, Евразийской экономической комиссии, проводились собственные расчеты на основе указанных данных. Результаты. Выявлено, что для борьбы с социально-экономическими последствиями пандемии коронавируса правительства разных стран реализовывали комплексные пакеты мер, предусматривавшие такие направления как: увеличение расходов на здравоохранение, прямая поддержка населения, сохранение занятости, содействие малому и среднему бизнесу, и наиболее пострадавшим секторам экономики. Общий объем антикризисной программы в России, рассчитанный в процентах от ВВП примерно в 2-3 раза меньше, чем в самых крупных мировых экономиках.
\end{abstract}




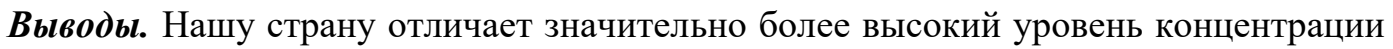
богатства в руках группы т.н. «сверхбогатых» граждан, по сравнению со среднемировым показателем и уровнем стран Восточной Европы, даже в условиях пандемии коронавируса. При этом динамика объемов инвестиций в основной капитал и прямых иностранных инвестиций, как возможных источников восстановления экономического роста, заметно отстает от динамики позиций России в некоторых международных рейтингах.

Ключевые слова: коронавирус, бедность, инвестиции, международные экономические рейтинги

Статья подготовлена в рамках государственного задания ИПР РАН, тема НИР «Моделирование прочессов обеспечения устойчивого и сбалансированного социально-экономического и пространственного развития России и стран ближнего зарубежья в целях формирования Большого евразийского партнерства».

\title{
Socio-economic consequences of the COVID-19 pandemic in Russia and other countries: analysis of anti-crisis programs, impact on the position in international rankings and prospects for recovery
}

\author{
Kobiljon Kh. Zoidov, Cand. of Sci. (Phys.\&Math.), Associate Professor \\ https://orcid.org/0000-0002-8474-0895; SPIN-code (RSCI): 2293-9802 \\ Scopus author ID: 57190430349 \\ e-mail: kobiljonz@mail.ru \\ Konstantin S. Jankauskas, Research fellow \\ https://orcid.org/0000-0003-2380-7088; SPIN-code (RSCI): 6937-4745 \\ e-mail: jankauskas.ipr.ras@gmail.com
}

\section{For citation}

Zoidov K.Kh., Jankauskas K.S. Socio-economic consequences of the COVID-19 pandemic in Russia and other countries: analysis of anti-crisis programs, impact on the position in international rankings and prospects for recovery // Market economy problems. - 2021. - No. 3. - Pp. 158-178 (In Russian).

DOI: https: //doi.org/10.33051/2500-2325-2021-3-158-178

\begin{abstract}
The article examines the socio-economic consequences of the COIVD-19 pandemic, such as the increase in poverty and social differentiation. Goal. To identify and analyze the socio-economic consequences of the COIVD-19 pandemic in Russia and other countries of the world, the measures taken by national governments to combat these consequences, as well as the dynamics of Russia's position in international economic rankings and the presence or absence of a connection between this dynamics and the dynamics of investment in the national economy. Objectives. Analysis of indicators of poverty and social stratification in Russia and the world in the context of the COIVD-19 pandemic; comparison of anti-crisis economic programs in the largest countries and Russia by GDP; study of the methodology of the most credible international economic rankings; comparative analysis of the dynamics of Russia's position in international economic rankings and the dynamics of capital investment and foreign direct investment in Russia. Methodology. The methods of system analysis, classification and comparison, evolutionary-institutional theory and historical approach were applied. Statistical and
\end{abstract}


other data of the Federal State Statistics Service of the Russian Federation, federal executive authorities of the Russian Federation, the Eurasian Economic Commission were used, and their own calculations were carried out on the basis of these data. Results. It was revealed that in order to combat the socio-economic consequences of the COVID19 pandemic, governments in different countries implemented comprehensive packages of measures including such as increasing health care costs, direct support for the population, maintaining employment, promoting small and medium-sized businesses, and the most affected sectors of the economy. The total volume of the anti-crisis program in Russia, calculated as a percentage of GDP, is about 2-3 times less than in the largest world economies. Conclusions. At the same time, our country is distinguished by a significantly higher level of concentration of wealth in the hands of a group of so-called «super-rich» citizens, compared to the global average and the level of Eastern European countries, even in the context of the COVID-19 pandemic. At the same time, the dynamics of the volume of capital investment and foreign direct investment, as possible sources of recovery of economic growth, significantly lags behind the dynamics of Russia's position in some international ratings.

Keywords: COVID-19, poverty, investment, international economic rankings

The article was prepared in the framework of the state task of the MEI RAS, the theme of research «Modeling the processes of ensuring sustainable and balanced socio-economic and spatial development of Russia and neighboring countries in order to form a Large Eurasian Partnership».

\section{Введение}

Существенное влияние на уровень бедности и социальное положение граждан во всем мире в 2020 и 2021 годах оказала и продолжает оказывать пандемия новой коронавирусной инфекции (COVID-19). Введение карантинов (локдаунов, режимов самоизоляции) разной степени жесткости и разной продолжительности привело к снижению объема ВВП и других макроэкономических показателей во многих странах мира, что в свою очередь повлекло сокращение доходов граждан, увеличение уровня бедности и социального неравенства. В этой связи представляется актуальным оценить масштабы увеличения показателей бедности и социального неравенства в России и других странах, а также проанализировать антикризисные программы поддержки экономики и граждан, которые правительства разных стран принимали в целях борьбы с экономическими последствиями пандемии коронавируса. Кроме того, следует рассмотреть динамику инвестиций в основной капитал и прямых иностранных инвестиций в Россию и попытаться выяснить, существует ли определенная зависимость данных показателей с позицией нашей страны в международных рейтингах. Эта задача является актуальной, поскольку именно увеличение темпов прироста инвестиций может быть одним из основных источников восстановления российской экономики после кризиса, связанного с последствиями пандемии коронавируса.

\section{Теоретическая база исследования}

Теоретические подходы к определению уровня абсолютной и относительной бедности, легшие, в том числе в основу применяемых до настоящего времени методик расчета уровня бедности, разрабатывались учеными с начала прошлого века. Британский ученый Б. Роунтри определял абсолютную линию бедности как стоимость годового или месячного минимально необходимого набора продуктов питания, одежды и обуви, а также платы за жилье (Rowentree, 1901). Американская ученая М. Оршански предложила рассчитывать черту бедности путем умножения стоимости минимальной продуктовой корзины на коэффициент, равный трем, основываясь на данных министерства сельского хозяйства США (Макоули, 1994). Дальнейшее развитие концепция абсолютной бедности, на основе которой рассчитывается уровень бедности в России, получила, в том числе в работах лауреата Нобелевской премии по экономике 1998 года А. Сена.

Проблемы рыночной экономики. - 2021. - № 3. - С. 158-178. 
Одним из основателей концепции относительной бедности является также ученый из Британии П. Таунсенд, обосновавший утверждение, что к числу бедных должны относиться граждане, чей уровень потребления и жизни существенно ниже стандартного (Townsend, 1979). По мнению П. Таунсенда, а также ряда других исследователей (С. Мака и Дж. Лансли, например) черта бедности должна определяться в качестве определенного процента (доли) от медианного дохода населения. На основе этого подхода рассчитывается уровень бедности во многих развитых странах, в т.ч. в США и странах Европейского союза.

Среди отечественных ученых, занимающихся теоретическими и практическими аспектами проблемы уровня бедности, хотелось бы отметить работы академика А.Ю. Шевякова, Л.Н. Овчаровой, Н.В. Зубаревич, Т.М. Малевой, В.Н. Бобкова и еще ряд других авторов.

\section{1. Динамика уровня бедности и социального неравенства в России и других странах мира в условиях пандемии коронавируса \\ Согласно ежегодному докладу Global Wealth Report исследовательского института} швейцарского банка Credit Suisse, благосостояние граждан России в первом полугодии 2020 года сократилось почти на $11 \%$ в долларовом выражении (The Global wealth report 2020). Богатство российских домохозяйств в расчете на одного взрослого в первом полугодии 2020 года упало на $10,7 \%$, что является одним из самых высоких темпов снижения среди исследованных стран - больше, чем в Колумбии, Великобритании и Турции, где темпы снижения богатства домохозяйств колебались в районе 6-7\%, а также больше, чем в Чили и на Украине, в которых этот показатель сократился примерно на 8-9\% (The Global wealth report 2020). Максимальное падение благосостояния граждан, согласно результатам исследования, зафиксировано в Мексике (на 14,2\%), ЮАР (на 21,8\%) и Бразилии (на 24,4\%). В абсолютном выражении совокупное благосостояние домохозяйств в России по оценке Credit Suisse в середине 2020 года составляло 3 трлн. долларов США, уменьшившись на 0,37 трлн. долларов США по сравнению с началом года. Среднее благосостояние в расчете на одного взрослого человека в России в середине 2020 года составляло 26,8 тысяч долларов США, сократившись на 3,2 тысячи долларов США по сравнению с началом года. Исследователи из Credit Suisse оценивают благосостояние домохозяйств по собственной методике, включая в расчет капитализацию фондового рынка страны, цены на жилье, валютные курсы и изменение объема ВВП. В первой половине 2020 года курс российского рубля по отношению к доллару США снизился на $13 \%$, что послужило основной причиной оценочного снижения богатства в долларовом выражении. По оценкам Credit Suisse, в целом в мире пандемия привела к сокращению богатства домохозяйств на 7,2 трлн. долларов США. Единственными странами, где благосостояние на одного взрослого человека увеличилось в первом полугодии 2020 года, стали Швейцария, Нидерланды, Тайвань и Гонконг (The Global wealth report 2020).

Сравнительный анализ данных за 2019 и 2020 годы, проведенный аналитиками Boston Consulting Group (BCG), показывает, что хотя темпы роста финансового благосостояния населения России опережали среднемировые, но этот опережающий рост основывается на значительном увеличении доходов сверхбогатых граждан во время пандемии коронавируса (Коржова, 2021). Темпы прироста финансового благосостояния в России в 2019-2020 годах в среднем составили 13\%, что выше среднемировых темпов прироста и темпов прироста в среднем по Восточной Европе, которые составили 8,3\% и 12\% (Коржова, 2021). При этом согласно расчетам BCG, самая большая доля финансового богатства в России принадлежит сверхбогатым людям, чье состояние исчисляется более 100 млн. долларов США. В 2020 году 500 богатейшим россиянам, которые составляют менее $0,0001 \%$ взрослого населения страны, принадлежало 40\% всех финансовых активов страны или около 640 млрд. долларов США (Коржова, 2021). Следует также отметить, что согласно исследованию BCG среднемировая доля концентрации финансового благосостояния в руках сверхбогатых граждан составляет $13 \%$, что в три раза меньше, чем в России (Коржова, 2021). По прогнозам авторов исследования в России этот показатель вырастет до 41\% к 2025 году, а в абсолютном выражении число граждан с состоянием более 100 млн. долларов США увеличится с 500 до 700 человек (Коржова, 2021). 
Во время первой волны пандемии коронавируса весной и летом 2020 года уровень абсолютной бедности в России вырос, согласно данным Росстата, что еще раз подтверждает факт крайне неравномерного распределения национального дохода в нашей стране. В таблице 1 приведены данные по уровню абсолютной бедности в России за последние 5 лет.

Таблица 1 / Table 1

Динамика уровня абсолютной бедности в России в 2015-2020 гг. / Dynamics of the level of absolute poverty in Russia in 2015-2020

\begin{tabular}{||c|c|c||}
\hline Год & $\begin{array}{c}\text { Численность населения с } \\
\text { доходами ниже прожиточного } \\
\text { минимума, млн. человек }\end{array}$ & $\begin{array}{c}\text { Доля населения с доходами } \\
\text { ние \%рожиточного минимума, } \\
\text { от общей численности } \\
\text { населения (уровень } \\
\text { абсолютной бедности) }\end{array}$ \\
\hline 2015 & 19,6 & 13,4 \\
\hline 2016 & 19,4 & 13,2 \\
\hline 2017 & 18,9 & 12,9 \\
\hline 2018 & 18,4 & 12,6 \\
\hline I квартал 2019 & 20,9 & 14,3 \\
\hline II квартал 2019 & 18,6 & 12,7 \\
\hline III квартал 2019 & 17,6 & 12,0 \\
\hline IV квартал 2019 & 13,5 & 9,2 \\
\hline 2019 & 18,1 & 12,3 \\
\hline I квартал 2020 & 18,6 & 12,6 \\
\hline II квартал 2020 & 19,9 & 13,5 \\
\hline III квартал 2020 & 18,8 & 12,8 \\
\hline IV квартал 2020 & 13,5 & 12,1 \\
\hline 2020 & 17,8 & 3,2 \\
\hline
\end{tabular}

Источник: / Sоигсе: (Цветков, Зоидов, Янкаускас и Кобил, 2018; Цветков, Зоидов, Янкаускас и Кобил, 2020; О соотношении денежных доходов населения с величиной прожиточного минимума и численности малоимущего населения в иелом по Российской Федерации в IV квартале 2020 года). I (Tsvetkov, Zoidov, Yankauskas and Kobil, 2018; Tsvetkov, Zoidov, Yankauskas and Kobil, 2020; On the ratio of the monetary income of the population to the subsistence minimum and the number of poor people in the Russian Federation as a whole in the fourth quarter of 2020).

Как видно из данных, представленных в таблице 1, во II и III квартале 2020 года наблюдался рост уровня абсолютной бедности в России по сравнению с уровнем II и III квартала 2019 года. Во II квартале 2020 года численность граждан за чертой абсолютной бедности была на 1,3 млн. человек выше, чем за аналогичный период 2019 года. В III квартале 2020 года численность граждан за чертой абсолютной бедности была выше значения за III квартал 2019 года на 1,2 млн. человек. В IV квартале 2020 года уровень абсолютной бедности снизился до показателей, идентичных IV кварталу 2019 года - 13,5 млн. человек или 9,2\% населения. Согласно данным Росстата, основными факторами снижения уровня абсолютной бедности в IV квартале 2020 года стали:

- увеличение общего объема социальных выплат - на 5,9\% по сравнению с уровнем IV квартала 2019 года;

- увеличение объема доходов от собственности - на 34,6\% по сравнению с уровнем III квартала 2020 года;

- увеличение объема доходов от предпринимательской и иной производственной деятельности - на 22,5\% по сравнению с уровнем III квартала 2020 года (Росстат рассчитал численность населения с доходами ниже прожиточного минимума в IV квартале 2020 года и за 2020 год в целом).

Стоит также отметить, что по данным Росстата размер прожиточного минимума в IV квартале 2020 года (черта абсолютной бедности) сократился на 2,4\% по сравнению с III 
кварталом 2020 года - с 11606 до 11239 рублей (Росстат рассчитал численность населения с доходами ниже прожиточного минимума в IV квартале 2020 года и за 2020 год в целом). В целом за 2020 год уровень абсолютной бедности оказался ниже уровня 2019 года на $0,2 \%$ или примерно на 300 тысяч человек. Однако, судя по поквартальной динамике, это снижение было обеспечено в первую очередь за счет «допандемийного» I квартала 2020 года, в котором численность граждан за чертой абсолютной бедности была ниже уровня I квартала 2019 года на 2,3 млн. человек.

2. Антикризисные меры национальных правительств по борьбе с экономическими последствиями пандемии коронавируса

Описанное выше снижение доходов и благосостояния граждан вынудило в 2020 году правительства разных стран принимать антикризисные программы, направленные на поддержку граждан, отдельных секторов и национальной экономики в целом. Данные антикризисные программы, принятые в отдельных странах, систематизированы в таблице 2.

Таблица 2 / Table 2

Антикризисные меры национальных правительств отдельных стран по борьбе с экономическими последствиями пандемии коронавируса в 2020 году /

Anti-crisis measures of national governments of individual countries to combat the economic consequences of the coronavirus pandemic in 2020

\begin{tabular}{|c|c|c|c|}
\hline Страна & Описание антикризисных мер & $\begin{array}{c}\text { Общая } \\
\text { стоимость } \\
\text { антикризисной } \\
\text { программы } \\
\end{array}$ & $\begin{array}{c}\text { Объем } \\
\text { антикризисной } \\
\text { программы в \% } \\
\text { от ВВП страны }\end{array}$ \\
\hline США & $\begin{array}{l}\text { Единоразовые денежные выплаты налич- } \\
\text { ными в апреле и мае } 2020 \text { года общей } \\
\text { стоимостью } 500 \text { млрд. долларов США: } \\
\bullet \quad 1200 \text { долларов США каждому } \\
\text { гражданину с доходом менее } 75 \text { 000 } \\
\text { долларов США в год; } \\
\bullet 500 \text { долларов США на каждого } \\
\text { ребенка в семье, совместный доход } \\
\text { которой менее } 120000 \text { долларов США в } \\
\text { год. } \\
\text { Кроме того, министерство финансов } \\
\text { выделяет } 300 \text { млрд. долларов США на } \\
\text { кредитование малого бизнеса, } 150 \text { млрд. } \\
\text { долларов США на гарантии по кредитам } \\
\text { предприятий из проблемных отраслей } \\
\text { экономики и отдельно } 50 \text { млрд. долларов } \\
\text { США на поддержку авиационной индуст- } \\
\text { рии, одной из наиболее пострадавших от } \\
\text { пандемии. Федеральная резервная система } \\
\text { США организует программу выкупа } \\
\text { активов стоимостью } 700 \text { млрд. долларов } \\
\text { США и выделяет } 2 \text { трлн. долларов СШа } \\
\text { на операции РЕПО. Заморожены выплаты } \\
\text { студенческих кредитов на } 2 \text { месяца и } \\
\text { введена отсрочка подачи налоговых } \\
\text { деклараций. }\end{array}$ & $\begin{array}{c}2 \text { трлн. долларов } \\
\text { США }\end{array}$ & $\sim 10 \%$ \\
\hline Китай & $\begin{array}{l}\text { Стоимость антикризисных бюджетных } \\
\text { мер составила 1,3 трлн. юаней (примерно } \\
1,2 \% \text { от ВВП), расходованных по следую- } \\
\text { щим направлениям: увеличение расходов } \\
\text { на профилактику эпидемий и борьбу с } \\
\text { ними, производство медицинского обору- } \\
\text { дования, ускорение выплаты пособий по } \\
\text { безработице, налоговые льготы и осво- } \\
\text { бождение предпринимателей от взносов в } \\
\text { систему социального обеспечения. } \\
\text { В дополнение к программе фискальных } \\
\text { мер Народный банк Китая осуществил }\end{array}$ & 6,47 трлн. юаней & $\sim 6,5 \%$ \\
\hline
\end{tabular}

Проблемы рыночной экономики. - 2021. - № 3. - С. 158-178. 


\begin{tabular}{|c|c|c|c|}
\hline Страна & Описание антикризисных мер & $\begin{array}{c}\text { Общая } \\
\text { стоимость } \\
\text { антикризисной } \\
\text { программы } \\
\end{array}$ & $\begin{array}{c}\text { Объем } \\
\text { антикризисной } \\
\text { программы в \% } \\
\text { от ВВП страны }\end{array}$ \\
\hline & $\begin{array}{l}\text { следующие меры поддержки банковского } \\
\text { и нефинансового секторов экономики: } \\
\bullet \text { увеличение ликвидности в нацио- } \\
\text { нальной банковской системе на } 3 \text { трлн. } \\
\text { юаней в первой половине февраля } 2020 \\
\text { года и } 20 \text { млрд. юаней в конце марта; } \\
\bullet \text { запуск программы перекредитова- } \\
\text { ния и субсидирования процентных ставок } \\
\text { для поддержки производителей медицин- } \\
\text { ского оборудования, предметов первой } \\
\text { необходимости, предприятий малого и } \\
\text { среднего бизнеса, а также сельскохозяй- } \\
\text { ственного сектора на общую сумму } 1,8 \\
\text { трлн. юаней; } \\
\bullet \quad \text { снижение нормы обязательного } \\
\text { резервирования с 13\% до 12,5\%, высво- } \\
\text { бодившее дополнительно примерно } 800 \\
\text { млрд. юаней ликвидности в банковской } \\
\text { системе; } \\
\bullet \text { предоставление кредитов в размере } \\
350 \text { млрд. юаней микро- и малым } \\
\text { предприятиям; } \\
\bullet \text { предоставление отсрочки по креди- } \\
\text { там для предприятий малого и среднего } \\
\text { бизнеса и домохозяйств. } \\
\bullet \text { смягчение политики местных орга- } \\
\text { нов власти в сфере жилищного строитель- } \\
\text { ства. }\end{array}$ & & \\
\hline Япония & $\begin{array}{l}\text { Пакет экстренной социальной помощи } \\
\text { включает в себя: } \\
\bullet \text { предоставление субсидий внештат- } \\
\text { ным сотрудникам/фрилансерам в размере } \\
4100 \text { иен на человека, которые вынуж- } \\
\text { дены уволиться из-за необходимости } \\
\text { ухода за детьми, приостановившими обу- } \\
\text { чение в школах вследствие их закрытия; } \\
\text { • списание процентов и тела кредита } \\
\text { при падении доходов граждан на } 30 \% \text { и } \\
\text { более. } \\
\text { Малому и среднему бизнесу предостав- } \\
\text { ляются беспроцентные займы, в случае } \\
\text { нехватки доступных денежных средств } \\
\text { из-за резкого падения продаж. }\end{array}$ & $\begin{array}{c}\text { 19,6 млрд. } \\
\text { долларов США }\end{array}$ & $\sim 0,43 \%$ \\
\hline Германия &  & 356 млрд. евро & $\sim 10 \%$ \\
\hline
\end{tabular}




\begin{tabular}{|c|c|c|c|}
\hline Страна & Описание антикризисных мер & $\begin{array}{c}\text { Общая } \\
\text { стоимость } \\
\text { антикризисной } \\
\text { программы }\end{array}$ & $\begin{array}{c}\text { Объем } \\
\text { антикризисной } \\
\text { программы в \% } \\
\text { от ВВП страны }\end{array}$ \\
\hline & $\begin{array}{l}\text { просрочки по уплате налогов } \\
\text { предприятиям внем } \\
\text { размера. }\end{array}$ & & \\
\hline Великобритания & $\begin{array}{l}\text { Налоговые и бюджетные меры поддержки } \\
\text { экономики включают в себя: дополни- } \\
\text { тельное финансирование здравоохранения } \\
\text { и других государственных служб, меры по } \\
\text { поддержке бизнеса, включая каникулы по } \\
\text { налогу на имущество, прямые гранты для } \\
\text { небольших фирм в наиболее пострадав- } \\
\text { ших секторах экономики и компенсацию } \\
\text { за отпуск по болезни, а также укрепление } \\
\text { системы социальной защиты для } \\
\text { поддержки уязимых людей с помощью } \\
\text { увеличения выплат по схеме универ- } \\
\text { сального кредита и расширения других } \\
\text { льгот. Правительство также запустило } \\
\text { схему кредитования на случай преры- } \\
\text { вания деятельности компаний малого и } \\
\text { среднего бизнеса - отсрочка уплаты } \\
\text { налога на добавленную стоимость на } \\
\text { следующий квартал до конца финансового } \\
\text { года; выплата 80\% заработной платы } \\
\text { занятых работников в течение } 3 \text { месяцев. }\end{array}$ & $\begin{array}{c}\text { 705,3 млрд. } \\
\text { долларов США }\end{array}$ & $\sim 25 \%$ \\
\hline Индия & $\begin{array}{l}\text { В рамках пакета антикризисных мер } \\
\text { правительство предоставляет прямые де- } \\
\text { нежные субсидии бедным - единоразовая } \\
\text { выплата эквивалентная 13,31 доллара } \\
\text { США на человека } 30 \text { миллионам пожилых } \\
\text { людей и ежемесячная выплата эквивален- } \\
\text { тная } 6,65 \text { долларов США на человека для } \\
200 \text { миллионов бедных женщин в течение } \\
3 \text { месяцев. Организуется бесплатная раз- } \\
\text { дача по } 5 \text { килограммов пшеницы или риса } \\
\text { на человека и дополнительно по кило- } \\
\text { грамму бобов каждой малообеспеченной } \\
\text { семье, а также оплата газа для приготовле- } \\
\text { ния еды } 83 \text { миллионам бедных семей. } \\
\text { Оплачивается расширенная медицинская } \\
\text { страховка для врачей и среднего медицин- } \\
\text { ского персонала. }\end{array}$ & $\begin{array}{l}1,7 \text { трлн. рупий } \\
\text { (22,5 млрд. } \\
\text { долларов США) }\end{array}$ & $\sim 1 \%$ \\
\hline Франция & $\begin{array}{l}\text { Правительственный план предусматри- } \\
\text { вает привлечение } 345 \text { млрд. евро. Из них } \\
300 \text { млрд. евро - для государственного } \\
\text { гарантирования кредитов предприятий, } \\
\text { особенно малого и среднего бизнеса, } 45 \\
\text { млрд. евро - для прямой помощи } \\
\text { предприятиям. Повышение гарантий по } \\
\text { кредитам, предоставленным МСП, с } 70 \% \\
\text { до 90\% от суммы заимствований. } \\
\text { Создание «фонда солидарности» для } \\
\text { предприятий, вынужденных приостано- } \\
\text { вить деятельность, и малых предприятий, } \\
\text { чья выручка сократилась на 70\% в марте } \\
2020 \text { года. Размер фонда составил } 1 \text { млрд. } \\
\text { евро каждый месяц, срок работы - два } \\
\text { месяца. }\end{array}$ & 345 млрд. евро & $\sim 14 \%$ \\
\hline Италия & $\begin{array}{l}\text { Пакет стимулирующих мер, включающих, } \\
\text { в том числе следующие: } \\
\text { • ипотечные каникулы сроком на } 9 \\
\text { месяцев под государственные гарантии } \\
\text { для самозанятых и других работников, не } \\
\text { получающих заработную плату и чьи } \\
\text { доходы, снизились более чем на треть в }\end{array}$ & 28 млрд. долларов & $\sim 1,4 \%$ \\
\hline
\end{tabular}




\begin{tabular}{|c|c|c|c|}
\hline Страна & Описание антикризисных мер & $\begin{array}{c}\text { Общая } \\
\text { стоимость } \\
\text { антикризисной } \\
\text { программы } \\
\end{array}$ & $\begin{array}{c}\text { Обьем } \\
\text { антикризисной } \\
\text { программы в \% } \\
\text { от ВВП страны }\end{array}$ \\
\hline & $\begin{array}{l}\text { период эпидемии; } \\
\bullet \text { выплаты в размере } 500 \text { евро для } \\
\text { самозанятых; } \\
\bullet \text { государственные гарантии до } 5 \text { млн. } \\
\text { евро для кредитования малых и средних } \\
\text { предприятий; } \\
\bullet \text { выплаты пособий по 15-дневному } \\
\text { отпуску для работников частного сектора } \\
\text { с детьми младше } 12 \text { лет; } \\
\bullet \quad \text { отмена подоходного налога для } \\
\text { малого бизнеса в марте и апреле } 2020 \\
\text { года; } \\
\bullet \text { отсрочка платежей за коммунальные } \\
\text { услуги в наиболее пострадавших от } \\
\text { пандемии муниципалитетах. }\end{array}$ & & \\
\hline Канада & 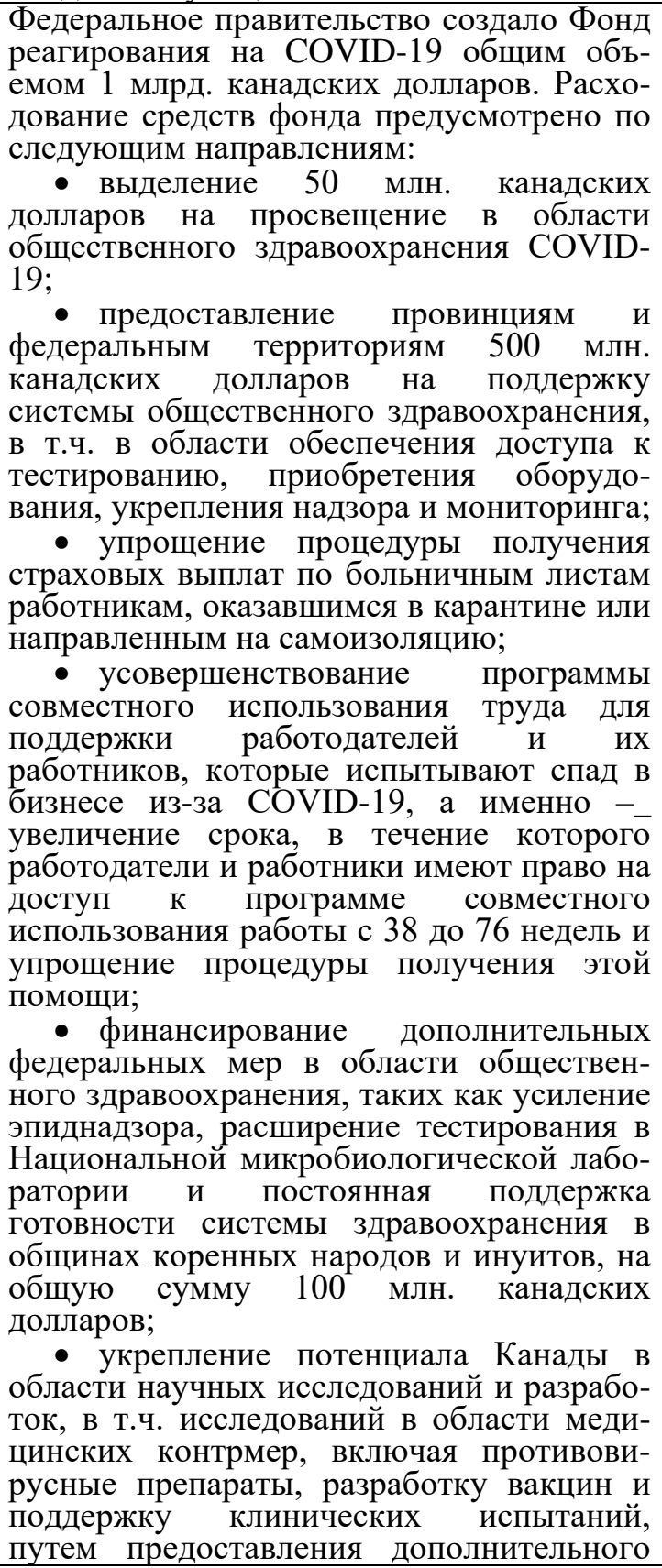 & $\begin{array}{c}1 \text { млрд. канадских } \\
\text { долларов }\end{array}$ & $\sim 0,05 \%$ \\
\hline
\end{tabular}




\begin{tabular}{|c|c|c|c|}
\hline Страна & Описание антикризисных мер & $\begin{array}{c}\text { Общая } \\
\text { стоимость } \\
\text { антикризисной } \\
\text { программы }\end{array}$ & $\begin{array}{c}\text { Объем } \\
\text { антикризисной } \\
\text { программы в \% } \\
\text { от ВВП страны }\end{array}$ \\
\hline & $\begin{array}{l}\text { финансирования в размере } 275 \text { миллионов } \\
\text { канадских долларов; } \\
\text { • обеспечение поставок средств } \\
\text { индивидуальной защиты, таких как } \\
\text { хирургические маски, защитные маски } \\
\text { для лица и изолирующие халаты, общей } \\
\text { стоимостью 50 миллионов канадских } \\
\text { долларов; } \\
\text { - решение проблемы глобальной } \\
\text { вспышки коронавируса и помощь более } \\
\text { уязвимым странам для борьбы с } \\
\text { пандемией через дополнительный взнос в } \\
\text { размере } 50 \text { млн. канадских долларов для } \\
\text { поддержки усилий Всемирной органи- } \\
\text { зации здравооханения и других партне- } \\
\text { ров. }\end{array}$ & & \\
\hline Южная Корея & $\begin{array}{l}23 \text { марта } 2020 \text { года национальное прави- } \\
\text { тельство удвоило первоначальный пакет } \\
\text { стимулирования экономики до } 100 \text { трлн. } \\
\text { вон. Меры предусматривают поддержку } \\
\text { малого и среднего бизнеса (29,1\% } \\
\text { выделенных средств), фондового рынка } \\
\text { (10,7\%), а также покупку корпоративных } \\
\text { облигаций. Стимулирующие меры для } \\
\text { предприятий малого и среднего бизнеса } \\
\text { включают в себя: субсидии для покрытия } \\
\text { издержек на оплату труда, кредитование } \\
\text { под сниженный процент субъектов малого } \\
\text { и среднего бизнеса, находящихся на } \\
\text { территориях, наиболее пострадавших от } \\
\text { пандемии, расширение программ страхо- } \\
\text { вания дебиторской задолженности, финан- } \\
\text { сирование программ сохранения рабочих } \\
\text { мест, стимулирование малого бизнеса к } \\
\text { расширению объема онлайн-продаж. } \\
\text { Среди мер прямой поддержки населения } \\
\text { были приняты: } \\
\text { • увеличение размера пособий по } \\
\text { безработице; } \\
\text { • выпуск продуктовых ваучеров для } \\
\text { семей с низким уровнем доходов; } \\
\text { • прямые выплаты всем семьям, за } \\
\text { исключением } 30 \text { процентов с наиболь- } \\
\text { шими доходами. }\end{array}$ & $\begin{array}{c}100 \text { трлн. вон } \\
\text { (примерно } 80 \\
\text { млрд. долларов } \\
\text { США) }\end{array}$ & $\sim 6 \%$ \\
\hline Австралия & $\begin{array}{l}\text { Правительство объявило о двух пакетах } \\
\text { экономических мер реагирования, кот- } \\
\text { рые в сумме стоили, по предварительным } \\
\text { оценкам, } 189 \text { млрд. долларов США. } \\
\text { Пакеты помощи включают в себя } \\
\text { своевременную поддержку пострадавших } \\
\text { работников предприятий и общественного } \\
\text { сектора. Были осуществлены прямые } \\
\text { выплаты пенсионерам, ветеранам и } \\
\text { инвалидам в размере } 750 \text { долларов США } \\
\text { на одного человека. Также был принят } \\
\text { комплекс следующих мер по поддержке } \\
\text { предприятий малого и среднего бизнеса: } \\
\text { - субсидирование заработной платы } \\
\text { стажеров в размере 50\% оклада на срок до } \\
9 \text { месяцев; } \\
\text { • снижение амортизационных отчис- } \\
\text { лений до 50\% (изменение налоговой нор- } \\
\text { мы амортизации); }\end{array}$ & $\begin{array}{c}189 \text { млрд. } \\
\text { долларов США }\end{array}$ & $\sim 10 \%$ \\
\hline
\end{tabular}




\begin{tabular}{|c|c|c|c|}
\hline Страна & Описание антикризисных мер & $\begin{array}{c}\text { Общая } \\
\text { стоимость } \\
\text { антикризисной } \\
\text { программы }\end{array}$ & $\begin{array}{c}\text { Объем } \\
\text { антикризисной } \\
\text { программы в \% } \\
\text { от ВВП страны }\end{array}$ \\
\hline & $\begin{array}{l}\text { • полугодовая отсрочка погашения } \\
\text { кредитов для малого бизнеса; прямые } \\
\text { выплаты в размере от } 2 \text { до } 25 \text { тысяч } \\
\text { долларов США для поддержки движения } \\
\text { денежного потока (выплаты не облагают- } \\
\text { ся налогами). }\end{array}$ & & \\
\hline Испания & $\begin{array}{l}\text { Комплексный пакет мер общей стои- } \\
\text { мостью 200 млрд. евро по поддержке } \\
\text { занятости и уязвимых групп населения, } \\
\text { пострадавших от коронакризиса. Среди } \\
\text { прочего применяютя следующие меры: } \\
\text { • увеличение выплат по больничным } \\
\text { листам для работников, инфицированных } \\
\text { COVID-19, или тех, кто находится в } \\
\text { карантине, с } 60 \text { до 75\% от нормативной } \\
\text { базы; } \\
\text { • увеличение пособий для само- } \\
\text { занятых работников, пострадавших в } \\
\text { результате приостановления экономи- } \\
\text { ческой деятельности; } \\
\text { • субсидирование автономных сооб- } \\
\text { ществ для финансирования питания детей, } \\
\text { пострадавших в результате закрытия } \\
\text { школ; расширение социальных пособий на } \\
\text { энергоснабжение; } \\
\text { • освобождение от уплаты социаль- } \\
\text { ных взносов пострадавших компаний, } \\
\text { которые подерживают панятость; } \\
\text { отсрочка налоговых платежей для малых } \\
\text { и средних предприятий и самозанятых на } \\
\text { шесть месяцев; } \\
\text { • 50-процентное освобождение рабо- } \\
\text { тодателя от взносов на социальное } \\
\text { обеспечение с февраля по июнь } 2020 \text { года } \\
\text { в секторе туризма и связанной с ним } \\
\text { деятельности. }\end{array}$ & $\begin{array}{c}200 \text { млрд. евро } \\
\text { (из них } 117 \text { млрд. } \\
\text { евро - из } \\
\text { государственного } \\
\text { бюджета, } \\
\text { остальная сумма - } \\
\text { от частных } \\
\text { компаний) }\end{array}$ & $\sim 17 \%$ \\
\hline Тайвань & $\begin{array}{l}\text { В рамках первого пакета поддержки (60 } \\
\text { млрд. тайваньских долларов) предусмот- } \\
\text { рено выделение «стимулирующих купо- } \\
\text { нов», а также субсидий для населения и } \\
\text { предпринимателей. Средства второго } \\
\text { пакета (40 млрд. тайваньских долларов) } \\
\text { будут преимущественно направлены на } \\
\text { поддержку наиболее пострадавших от } \\
\text { коронавируса отраслей экономики (в том } \\
\text { числе авиакомпаний). }\end{array}$ & $\begin{array}{c}100 \text { млрд. } \\
\text { тайваньских } \\
\text { долларов } \\
\text { (примерно } 3,3 \\
\text { млрд. долларов } \\
\text { США) }\end{array}$ & $\sim 1 \%$ \\
\hline Таиланд & $\begin{array}{l}\text { Кабинет министров утвердил меры } \\
\text { бюджетного стимулирования, состоящие } \\
\text { из расходов на здравоохранение, льготное } \\
\text { кредитование и поддержку бизнеса, а } \\
\text { также принял ряд мер по оказанию } \\
\text { помощи должникам, включая выдачу } \\
\text { дополнительных кредитов для оборотного } \\
\text { капитала, ссуд с низкой процентной } \\
\text { ставкой и другое. Учрежден Фонд } \\
\text { стабилизации корпоративных облигаций } \\
\text { на сумму 70-100 млрд. бат. }\end{array}$ & $\begin{array}{c}518 \text { млрд. бат } \\
\text { (1,6 млрд. } \\
\text { долларов США) }\end{array}$ & $\sim 3 \%$ \\
\hline
\end{tabular}




\begin{tabular}{|c|c|c|c|}
\hline Страна & Описание антикризисных мер & $\begin{array}{c}\text { Общая } \\
\text { стоимость } \\
\text { антикризисной } \\
\text { программы }\end{array}$ & $\begin{array}{c}\text { Объем } \\
\text { антикризисной } \\
\text { программы в \% } \\
\text { от ВВП страны }\end{array}$ \\
\hline Дания & $\begin{array}{l}\text { Пакет мер включает в себя выделение } \\
\text { около 60 млрд. датских крон на } \\
\text { дополнительное финансирование здра- } \\
\text { воохранения, а также поддержку пред- } \\
\text { приятий и работников. Оставшаяся часть } \\
\text { средств направляется на компенсацию } \\
\text { сокращающихся налоговых поступлений } \\
\text { и увеличивающихся социальных отчисле- } \\
\text { ний. Освобождение банков от необходи- } \\
\text { мости поддержания «антициклического } \\
\text { буферного капитала», что обеспечит им } \\
\text { дополнительные 200 млрд. датских крон } \\
\text { ликвидности. Правительство также гаран- } \\
\text { тирует 70\% стоимости новых кредитов } \\
\text { крупным компаниям, падение оборота } \\
\text { которых составляет более 50\%. }\end{array}$ & $\begin{array}{c}120 \text { млрд. датских } \\
\text { крон (примерно } \\
17,6 \text { млрд. } \\
\text { долларов США) }\end{array}$ & $\sim 5 \%$ \\
\hline Гонконг & 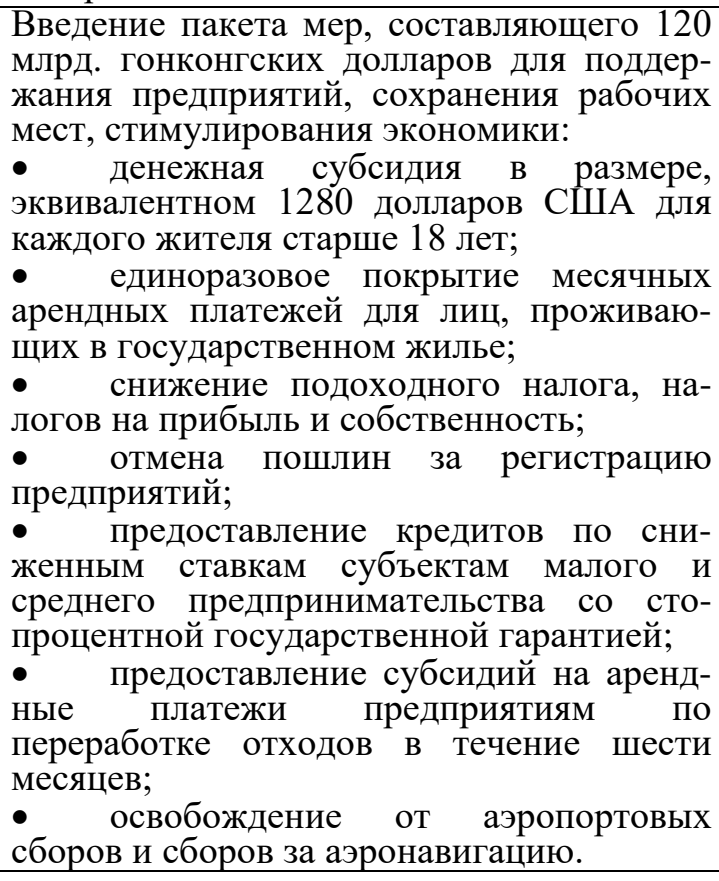 & $\begin{array}{c}15 \text { млрд. долларов } \\
\text { США }\end{array}$ & $\sim 4,5 \%$ \\
\hline Финляндия & $\begin{array}{l}\text { По инициативе правительства парламент } \\
\text { Финляндии принял поправку об } \\
\text { увеличении бюджета на 2020 год, } \\
\text { предусматривающую меры антикризисной } \\
\text { поддержки объемом в } 1,06 \text { млрд. евро, из } \\
\text { которых около 60\% направлено на } \\
\text { поддержание авиационной отрасли и } \\
\text { примерно по } 20 \% \text { на поддержку малого } \\
\text { бизнеса и государственное управление. }\end{array}$ & 1,06 млрд. евро & $\sim 0,44 \%$ \\
\hline Новая Зеландия & $\begin{array}{l}\text { Пакет антикризисных мер общей } \\
\text { стоимостью 12,1 млрд. новозеландских } \\
\text { долларов включал в себя: } \\
\text { • увеличение расходов на здравоохра- } \\
\text { нение - } 500 \text { млрд. новозеландских долла- } \\
\text { ров; } \\
\text { • субсидии на заработную плату для } \\
\text { пострадавших предприятий во всех } \\
\text { секторах и регионах - } 5,1 \text { млрд. } \\
\text { новозеландских долларов; } \\
\text { • оплата больничного по COVID-19 и } \\
\text { поддерживающие выплаты для граждан, } \\
\text { оказавшихся на самоизоляции - } 126 \text { млн. }\end{array}$ & $\begin{array}{c}\text { 12,1 млрд. } \\
\text { новозеландских } \\
\text { долларов }\end{array}$ & $\sim 4 \%$ \\
\hline
\end{tabular}




\begin{tabular}{|c|c|c|c|}
\hline Страна & Описание антикризисных мер & $\begin{array}{c}\text { Общая } \\
\text { стоимость } \\
\text { антикризисной } \\
\text { программы } \\
\end{array}$ & $\begin{array}{c}\text { Обьем } \\
\text { антикризисной } \\
\text { программы в \% } \\
\text { от ВВП страны }\end{array}$ \\
\hline & $\begin{array}{l}\text { новозеландских долларов; } \\
\bullet \text { программа перемещения рабочих на } \\
\text { альтернативные рабочие места, взамен } \\
\text { потерянных из-за пандемии - } 100 \text { млн. } \\
\text { новозеландских долларов; } \\
\bullet \text { пакет поддержки доходов для } \\
\text { наиболее уязвимых слоев населения, в т.ч. } \\
\text { еженедельная выплата размером } 25 \\
\text { новозеландских долларов и удвоение } \\
\text { компенсации за зимнее отопление в } 2020 \\
\text { году - 2,8 млрд. новозеландских долларов; } \\
\bullet \text { изменения в системе налогообло- } \\
\text { жения на бизнес для высвобождения } \\
\text { денежного потока, в т.ч. временное } \\
\text { повышение налогового порога, восста- } \\
\text { новление амортизации зданий и списание } \\
\text { процентов за просроченную уплату налога } \\
\text { - 2,8 млрд. новозеландских долларов; } \\
\bullet \text { поддержка авиационной отрасли - } \\
600 \text { млн. новозеландских долларов. }\end{array}$ & & \\
\hline
\end{tabular}

Источник: / Source: (Обзор мирового опыта по борьбе с коронавирусом от 16 апреля 2020 г.; Spain unveils «unprecedented» 200 billion euros coronavirus package; \$12.1 billion support for New Zealanders and business; India outlines $\$ 23$ billion stimulus to help poor hit by lockdown; Prime Minister outlines Canada's COVID-19 response); расчеты авторов / (Review of the world experience in combating COVID-19 pandemic from April 16, 2020, no. 1; Spain unveils «unprecedented» 200 billion euros coronavirus package; $\$ 12.1$ billion support for New Zealanders and business; India outlines $\$ 23$ billion stimulus to help poor hit by lockdown; Prime Minister outlines Canada's COVID-19 response); calculations of the authors.

Как видно из данных, представленных в таблице 2, общий объем национальных антикризисных программ по борьбе с экономическими последствиями пандемии коронавируса в рассматриваемых странах колебался от 0,05\% ВВП в Канаде до $25 \%$ ВВП в Великобритании. В большинстве антикризисных программ были задействованы такие меры, как:

- гарантии по кредитам, государственное кредитование или прямое субсидирование предприятий из государственного бюджета;

- меры по поддержке занятости;

- прямые выплаты всем гражданам или наиболее незащищенным и пострадавшим от экономического кризиса социальным группам;

- увеличение государственных расходов на здравоохранение;

- приобретение государством корпоративных облигаций;

- государственная поддержка отраслей, наиболее пострадавших от экономических последствий пандемии, прежде всего, авиационной и туристической;

• льготы на оплату гражданами коммунальных услуг и/или аренды жилья.

3. Антикризисные меры по борьбе с экономическими последствиями пандемии коронавируса в России

Вскоре после начала пандемии коронавируса в России правительство РФ зарезервировало 1,4 трлн. рублей на поддержку национальной экономики и граждан. К осени 2020 года общая стоимость пакета поддержки увеличилась в несколько раз. Около 176 млрд. рублей было потрачено на расходы, непосредственно связанные с лечением коронавирусной инфекции: закупку медицинского оборудования, доплаты к заработной плате врачей и перепрофилирование больниц для лечения коронавирусных больных (Отчет Михаила Мишустина о работе правительства. Стенограмма, 2020).

Правительство РФ выделило около 600 млрд. рублей на прямые выплаты семьям с детьми - дважды по 10 тысяч рублей на одного ребенка. Также правительством были выделены 
дополнительные средства на увеличение размера пособий по безработице (Отчет Михаила Мишустина о работе правительства. Стенограмма, 2020).

Чтобы смягчить ситуацию на рынке кредитования, в начале апреля Государственная дума приняла закон, согласно которому граждане и бизнес могут рассчитывать на кредитные каникулы. По данным Банка России, с 20 марта по 09 сентября 2020 года физические лица направили в банки 2,76 млн. обращений об изменении условий кредитного договора. Банки удовлетворили 1,66 млн. обращений, то есть примерно $60 \%$ от общего объема обращений на общую сумму в 750 млрд. рублей. Это составило $3,75 \%$ от всей задолженности домохозяйств (20,2 трлн. рублей по состоянию на 1 августа) (Динамика реструктуризации кредитов населения и бизнеса, 2020). Кроме того, была запущена программа льготной ипотеки по ставке $6,5 \%$. К концу июля в рамках данной программы было выдано 80 тысяч кредитов на общую сумму в 205 млрд. рублей.

Юридические лица (кроме малого и среднего бизнеса) с конца марта по начало сентября реструктурировали кредиты на 4,3 трлн. рублей, что составляет $13,3 \%$ от общего объема кредитного портфеля. Малый и средний бизнес реструктурировал кредиты на 753 млрд. рублей. Было одобрено 62\% направленных заявок. Были реструктурированы кредиты общей стоимостью 136,6 млрд. рублей, что составило около $33,4 \%$ общего объема задолженности малых и средних предприятий из отраслей, входящих в перечень наиболее пострадавших от пандемии коронавируса. Также банки выдавали беспроцентные кредиты на выплату зарплаты под гарантии Внешэкономбанка. Всего было выдано 40 тысяч таких кредитов на общую сумму в 93 млрд. рублей (Отчет Михаила Мишустина о работе правительства. Стенограмма, 2020).

Правительство РФ запустило программу льготного кредитования для пополнения оборотных средств системообразующих предприятий. По этой программе было выдано льготных кредитов на общую сумму в 139 млрд. рублей. Помимо этого, государственную поддержку получили отдельные отрасли, которые существенно зависят от потребительского спроса:

- авиакомпании - 23 млрд. рублей;

- туристические операторы получили субсидии на 3,5 млрд. рублей, еще 15 млрд. рублей выделено на развитие внутреннего туризма;

- на программу стимулирования спроса в автомобильной промышленности направлено 25 млрд. рублей;

- 15 млрд. рублей выделено на закупку самолетов и вертолетов для санитарной авиации;

- запущена программа субсидирования кредитов застройщиков на сумму 12 млрд. рублей;

- 200 млрд. рублей из федерального бюджета было выделено в бюджеты субъектов федерации на компенсацию выпадающих доходов (Отчет Михаила Мишустина о работе правительства. Стенограмма, 2020).

Таким образом, общая стоимость антикризисных мер, принятых правительством РФ во время пандемии коронавируса, оценивается министерством экономического развития примерно в 5-6\% от объема ВВП (Общая стоимость антикризисных мер в России составила 5-6\% ВВП). Если сравнивать объем антикризисной поддержки в процентах от ВВП с другими странами, то объем антикризисной поддержки в России примерно сопоставим с объемом поддержки в Дании и Южной Корее, но примерно в 2 раза меньше, чем в США, Австралии и Германии, примерно в 3 раза меньше, чем во Франции и Испании и в 5 раз меньше, чем в Великобритании. Некоторые ученые-экономисты считали общий объем антикризисных мер поддержки в России в период пандемии коронавируса недостаточным и предлагали увеличить его до сопоставимого с развитыми экономиками Европы и Северной Америки уровня в 10-15\% ВВП (Сонин, 2020, c. 43).

Поскольку одним из возможных источников экономического роста для восстановления экономики России после коронавирусного кризиса 2020 года может являться рост объема инвестиций в основной капитал, следует отдельно рассмотреть динамику данного показателя, а также попытаться исследовать существует ли его взаимосвязь с позицией России в ряде международных экономических рейтингов. 


\section{4. Позиция России в международных экономических рейтингах и динамика инвестиций в основной капитал и прямых иностранных инвестиций}

Среди международных экономических рейтингов, мониторинг которых осуществляют Министерство экономического развития РФ и Евразийская экономическая комиссия, наиболее значимыми в области оценки инвестиционного климата и потенциала для привлечения инвестиций являются следующие: рейтинг Всемирного банка Doing Business, Индекс глобальной конкурентоспособности Всемирного экономического форума и рейтинг журнала Forbes лучших стран для ведения бизнеса (Россия в международных рейтингах; Позиция ЕАЭС и государств-членов в международных рейтингах). Рассмотрим коротко методику расчета каждого из указанных рейтингов.

Рейтинг Всемирного банка Doing Business. Рейтинг составляется Всемирным банком с 2002 года и в настоящий момент охватывает 190 стран (О проекте «Ведение бизнеса»). Целью составления рейтинга, по словам его авторов, является оценка нормативно-правовой базы, регулирующей предпринимательскую деятельность, и ее применение (О проекте «Ведение бизнеса»). Совокупный рейтинг формируется по итогам исследований по 10 тематическим направлениям: создание предприятий, получение разрешений на строительство, подключение к системе энергоснабжения, регистрация собственности, получение кредитов, защита миноритарных инвесторов, налогообложение, международная торговля, обеспечение исполнения контрактов, разрешение неплатежеспособности (Методология рейтинга Doing Business).

Повышение позиции России в рейтинге Doing Business входило в список поручений президента РФ Владимира Путина правительству РФ согласно т.н. «майским указам» 2012 года. Согласно Указу Президента РФ от 07.05.2012 г. № 596 «О долгосрочной государственной экономической политике» правительству РФ было поручено принять меры для повышения позиции России в рейтинге Doing Business co 120 в 2011 году до 50 в 2015 году и до 20 в 2018 году (Указ Президента Российской Федерации от 07.05.2012 г. № 596 «О долгосрочной государственной экономической политике»).

Индекс глобальной конкурентоспособности Всемирного экономического форума. Данный индекс был разработан профессором Университета Колумбия в Нью-Йорке Хавьером Сала-и-Мартином и испанским экономистом Эльзой Артади и рассчитывается, начиная с 2004 года (Sala-i-Martin, Xavier and Elsa V. Artadi., 2004). В настоящий момент индекс охватывает 141 страну. Индекс измеряет набор институтов, политик и факторов, которые определяют устойчивый текущий и среднесрочный уровни экономического процветания (Global Competitiveness Network: Frequently Asked Questions). Расчет индекса осуществляется по следующим 12 компонентам: «Качество институтов», «Инфраструктура», «Макроэкономическая стабильность», «Конкурентоспособность компаний», «Здоровье и начальное образование», «Размер внутреннего рынка», «Высшее образование и профессиональная подготовка», «Эффективность рынка товаров и услуг», «Эффективность рынка труда», «Развитость финансового рынка», «Технологический уровень» и «Инновационный потенциал» (Global Competitiveness Network: Frequently Asked Questions). Две трети показателей по указанным компонентам рассчитываются по итогам Опроса руководителей (Executive Opinion Survey) - опроса репрезентативной выборки руководителей предприятий в странах, охватываемых исследованием (более 14300 человек в общей сложности) (The Global Competitiveness Report. Special edition 2020, с. 78). Еще одна треть показателей рассчитывается на основе статистических данных из открытых источников, таких как данные Международного валютного фонда, Всемирного банка и Организации Объединенных Наций (Global Competitiveness Network: Frequently Asked Questions).

Рейтинг Forbes лучших стран для ведения бизнеса. Данный рейтинг рассчитывается с 2006 года и охватывает 161 страну (Best Countries For Business 2019: Behind The Numbers). Итоговый рейтинг рассчитывается на основе 15 компонентов, каждый из которых одинаково взвешивается: права собственности, инновации, налоги, технологии, коррупция, инфраструктура, размер рынка, политический риск, качество жизни, рабочая сила, свобода (личная, торговая и монетарная), бюрократия и защита инвесторов (Best Countries For Business 2019: Behind The Numbers). В рейтинг включаются страны, по которым имеются данные хотя 
бы по 11 категориям. Рейтинг Forbes является, по сути «рейтингом рейтингов», поскольку при его расчете используются данные других рейтингов: рейтинга Doing Business для оценки компонентов «налоги», «защита инвесторов» и «бюрократия», Индекса экономической свободы - для компонентов «торговая» и «монетарная свобода», Индекса глобальной конкурентоспособности - для компонентов «технологии», «инновации» и «инфраструктура» (Best Countries For Business 2019: Behind The Numbers). Также для расчета рейтинга используются данные Международного индекса защиты прав собственности, Индекса восприятия коррупции, Индекса человеческого развития $\mathrm{OOH}$, статистические данные Всемирного банка (Best Countries For Business 2019: Behind The Numbers).

Динамика изменения позиций России в указанных трех международных рейтингах, a также сравнительная динамика инвестиций в основной капитал и прямых иностранных инвестиций в экономику России представлены в таблице 3.

Таблица 3 / Table 3

Динамика позиций России в международных экономических рейтингах, а также темпов прироста инвестиций в основной капитал и прямых иностранных инвестиций в экономику России в 2015-2020 гг. / Dynamics of Russia's positions in international economic ratings, as well as the growth rates of investments in fixed assets and foreign direct investment in the Russian economy in 2015-2020.

\begin{tabular}{|l|c|c|c|c|c|c|c|}
\hline & $\mathbf{2 0 1 5}$ & $\mathbf{2 0 1 6}$ & $\mathbf{2 0 1 7}$ & $\mathbf{2 0 1 8}$ & $\mathbf{2 0 1 9}$ & $\mathbf{2 0 2 0}$ & $\begin{array}{c}\mathbf{2 0 2 0} \text { к } \\
\mathbf{2 0 1 3}\end{array}$ \\
\hline $\begin{array}{l}\text { Рейтинг Doing Вusiness, } \\
\text { позиция }\end{array}$ & 62 & 51 & 40 & 35 & 31 & 28 & $\begin{array}{c}+34 \\
\text { позиции }\end{array}$ \\
\hline $\begin{array}{l}\text { Индекс глобальной } \\
\text { конкурентоспособности, } \\
\text { позиция }\end{array}$ & 45 & 43 & 38 & 43 & 43 & -1 & $\begin{array}{c}+2 \\
\text { позиции }\end{array}$ \\
\hline $\begin{array}{l}\text { Рейтинг Fогбеs лучших стран } \\
\text { для ведения бизнеса, позиция }\end{array}$ & 81 & 79 & 58 & 58 & 55 & - & $\begin{array}{c}\text { +26 } \\
\text { позиций }\end{array}$ \\
\hline $\begin{array}{l}\text { Инвестиции в основной } \\
\text { капитал, темпы прироста в \% к } \\
\text { предыдущему году }\end{array}$ & $-11,1$ & $-0,2$ & 4,8 & 5,4 & 2,1 & $-1,4$ & - \\
\hline $\begin{array}{l}\text { Индекс инвестиций в } \\
\text { основной капитал, 2015 год - } \\
\text { 100\% }\end{array}$ & 100 & 99,8 & 104,6 & 110,2 & 112,6 & 111 & $+11 \%$ \\
\hline $\begin{array}{l}\text { Прямые иностранные } \\
\text { инвестиции в Россию, млрд. } \\
\text { долларов СшА }\end{array}$ & 6,85 & 32,54 & 28,56 & 8,79 & 31,98 & 8,66 & $+26,4 \%$ \\
\hline $\begin{array}{l}\text { Прямые иностранные } \\
\text { инвестиции в Россию, темпы } \\
\text { прироста в \% по сравнению с } \\
\text { предыдущим годом }\end{array}$ & $-68,9$ & 475 & $-12,1$ & $-69,2$ & 363,8 & $-72,9$ & - \\
\hline
\end{tabular}

Источник: / Soигсе: (Россия в международных рейтингах; Инвестиции в нефинансовые активы; Статистика внешнего сектора; Экономическое развитие Евразийского экономического союза и государств-членов в 2019 году: аналитический доклад); расчеты авторов / (Russia in the international rankings; Investments in non-financial assets; External sector statistics; Economic development of the Eurasian Economic Union and Member States in 2019: analytical report); calculations of the authors.

\footnotetext{
${ }^{1}$ В 2020 году индекс не рассчитывался в связи с пандемией коронавируса (Россия в международных рейтингах, с. 4).

2 Показатель 2019 года по сравнению с 2015 годом.

${ }^{3}$ Показатель 2019 года по сравнению с 2015 годом.
} 
Как видно из данных, представленных в таблице 3, за последние пять лет Россия заметно улучшила свои позиции в рейтинге Doing Business и рейтинге Forbes лучших стран для ведения бизнеса - на 34 и 26 позиций соответственно. В Индексе глобальной конкурентоспособности наша страна улучшила положение всего на 2 позиции. При этом индекс инвестиций в основной капитал в 2020 году составил $111 \%$ от уровня 2015 года. Динамика объема прямых иностранных инвестиций в 2015-2020 годах колебалась довольно сильно: минимальное значение составило 6,85 млрд. долларов США в 2015 году, максимальное - 32,54 млрд. долларов США в 2016 году.

Сравнение данных, приведенных в таблице 3 , показывает, что улучшение позиций в исследуемых международных рейтингах не оказывало прямого влияния на динамику инвестиций в основной капитал или объем прямых иностранных инвестиций в российскую экономику. В то время как позиция России в рейтинге Doing Business и рейтинге Forbes последовательно и заметно снижалась на протяжении всех последних пяти лет, динамика инвестиций в основной капитал и, особенно, прямых иностранных инвестиций носила более разнонаправленный характер. Можно предположить, что наблюдаемая динамика позиции России в рейтинге Doing Business связана в первую очередь с тем, что улучшение позиций в нем официально закреплено среди поручений правительству РФ от президента. Методика расчета данного рейтинга касается в основном нормативно-правовой базы, регулирующей предпринимательскую деятельность. Таким образом, улучшение позиций в данном рейтинге вполне может достигаться за счет исключительно формального улучшения нормативноправовой базы, никак не коррелирующего с основными макроэкономическими и производственными показателями. При этом позиция России в Индексе глобальной конкурентоспособности, не являющимся для федерального правительства «отчетным» перед президентом и состоящим из более разнообразного набора компонент, включая оценку показателей человеческого капитала, за прошедшие 5 лет практически не изменилась. Таким образом, можно сделать вывод о том, что позиция страны в исследованных международных рейтингах не может являться целью или критерием эффективности проводимой экономической политики и вряд ли напрямую может повлиять на объем и динамику инвестиций.

\section{Основные выводы}

1. Пандемия коронавируса привела к заметному росту уровня бедности и социального расслоения практически во многих странах мира, в том числе и в России. В разгар пандемии численность бедных в России увеличилась примерно на 1,2-1,3 млн. человек. При этом нашу страну отличает значительно более высокий уровень концентрации богатства в руках группы т.н. «сверхбогатых» граждан, по сравнению со среднемировым показателем и уровнем стран Восточной Европы. Данный показатель не удалось сгладить в ходе коронавирусного кризиса и по прогнозам экспертов он продолжит расти в ближайшие годы.

2. Для борьбы с экономическими и социальными последствиями пандемии коронавируса правительства разных стран реализовывали комплексные пакеты мер, предусматривавшие такие направления как увеличение расходов на здравоохранение, прямая поддержка населения, поддержание занятости, содействие малому и среднему бизнесу и наиболее пострадавшим секторам экономики.

3. Общий объем антикризисной программы, разработанной правительством РФ для борьбы с последствиями коронакризиса, составил примерно 5-6\% от объема ВВП. Это примерно сопоставимо с объемом аналогичных программ в Дании и Южной Корее, но примерно в 2 раза меньше, чем в США, Австралии и Германии, примерно в 3 раза меньше, чем во Франции и Испании и в 5 раз меньше, чем в Великобритании.

4. Увеличение объемов инвестиций в основной капитал, и в том числе прямых иностранных инвестиций, может быть одним из основных источников восстановления отечественной экономики после пандемии коронавируса. Однако пока что динамика объемов 
инвестиций в основной капитал и прямых иностранных инвестиций заметно отстает от динамики позиций России в некоторых международных рейтингах. Есть основания предполагать, что вместо стимулирования увеличения объемов инвестиций федеральное правительство занято задачей формального выполнения поручения президента по улучшению позиции России в международном рейтинге Doing Business.

\section{Литература / References}

1. “Динамика реструктуризации кредитов населения и бизнеса”, (14.09.2020), Банк России, Информаимонный бюллетень, № 6, доступно по адресу: https://www.cbr.ru/Collection/Collection/File/29235/drknb_06_2020.pdf (Дата обращения 21.06.2021). ["Dynamics of restructuring of loans to the population and business", (14.09.2020), Bank of Russia, Information bulletin, no. 6, available at: https://www.cbr.ru/Collection/Collection/File/29235/drknb_06_2020.pdf. (Accessed 21.06.2021)].

2. Инвестиции в нефинансовые активы, Официальный сайт Федеральной службы государственной статистики, доступно по адресу: https://rosstat.gov.ru/investment_nonfinancial (Дата обращения 21.06.2021). [Investments in non-financial assets, Official website of the Federal State Statistics Service, available at: https://rosstat.gov.ru/investment_nonfinancial (Accessed 21.06.2021)].

3. Коржова, Д. (2021), "Россия обогнала мир по росту благосостояния за счет сверхбогатых граждан", доступно по адресу: https://thebell.io/rossiya-obognala-mir-po-rostublagosostoyaniya-za-schet-sverhbogatyh-grazhdan (Дата обращения 10.06.2021). [Korzhova, D. (2021), "Russia has overtaken the world in terms of wealth growth at the expense of super-rich citizens", available at: https://thebell.io/rossiya-obognala-mir-po-rostu-blagosostoyaniya-za-schetsverhbogatyh-grazhdan (Accessed 10.06.2021)].

4. Макоули, А. (1994), “Определение и измерение бедности”, Бедность: взгляд ученых на проблему, под редакцией Можиной, М.А., ИСЭПН РАН, М. [Macauley, А. (1994), "Definition and measurement of poverty", Poverty: a view of scientists on the problem, ed. by Mozhina, M.A., ISEPN RAS, M.].

5. “Методология рейтинга Doing Business”, Всемирный банк, доступно по адресу: https://russian.doingbusiness.org/ru/methodology (Дата обращения 21.06.2021). ["Methodology of the Doing Business rating", The World Bank, available at: https://russian.doingbusiness.org/ru/methodology (Accessed 21.06.2021)].

6. "Обзор мирового опыта по борьбе с коронавирусом от 16 апреля 2020 г.", Коммуникаиионный центр при Правительстве Российской Федеращии, №1., доступно по адресу: http://www.gobogdanovich.ru/images/static/koronavirus/obzor-morovogo-opyta-po-borbe-skoronavirusom-16042020.pdf (Дата обращения 11.06.2021). ["Review of the world experience in combating COVID-19 pandemic from April 16, 2020", Communication Center under the Government of the Russian Federation, no. 1, available at: http://www.gobogdanovich.ru/images/static/koronavirus/obzormorovogo-opyta-po-borbe-s-koronavirusom-16042020.pdf. (Accessed 11.06.2021)].

7. Общая стоимость антикризисных мер в России составила 5-6\% ВВП, 19.10.2020, доступно по адресу: https://tass.ru/ekonomika/9753737 (Дата обращения 21.06.2021). [The total cost of anti-crisis measures in Russia was 5-6\% of GDP, 19.10.2020, available at: https://tass.ru/ekonomika/9753737 (Accessed 21.06.2021)].

8. "О проекте «Ведение бизнеса»", Всемирный банк, доступно по адресу: https://russian.doingbusiness.org/ru/about-us (Дата обращения 21.06.2021). [“About the project «Doing business»", The World Bank, available at: https://russian.doingbusiness.org/ru/about-us (Accessed 21.06.2021)]. 
9. “О соотношении денежных доходов населения с величиной прожиточного минимума и численности малоимущего населения в целом по Российской Федерации в IV квартале 2020 года", Федеральная служба государственной статистики, доступно по адресу: https://gks.ru/bgd/free/b04_03/IssWWW.exe/Stg/d02/66.htm (Дата обращения 10.06.2021). [“On the ratio of the monetary income of the population to the subsistence minimum and the number of poor people in the Russian Federation as a whole in the fourth quarter of 2020", Federal State Statistics Service, available at: https://gks.ru/bgd/free/b04_03/IssWWW.exe/Stg/d02/66.htm (Accessed 10.06.2021)].

10. Отчет Михаила Мишустина о работе правительства. Стенограмма, (2020), доступно по адресу: https://rg.ru/2020/07/22/otchet-mihaila-mishustina-o-rabote-pravitelstvastenogramma.html (Дата обращения 21.06.2021). [Mikhail Mishustin's report on the work of the Government, Transcript, (2020), available at: https://rg.ru/2020/07/22/otchet-mihaila-mishustina-orabote-pravitelstva-stenogramma.html (Accessed 21.06.2021)].

11. "Позиция ЕАЭС и государств-членов в международных рейтингах", Официальный сайт Евразийской экономической комиссии, доступно по адресу: https://eec.eaeunion.org/comission/department/dep_makroec_pol/rankings.php (Дата обращения 21.06.2021). ["The position of the EAEU and its member states in the international rankings", Official website of the Eurasian Economic Commission, available at: https://eec.eaeunion.org/comission/department/dep_makroec_pol/rankings.php (Accessed 21.06.2021)].

12. "Россия в международных рейтингах", Офищиальный сайт Министерства экономического развития Российской Федерации, доступно по адресу: http://old.economy.gov.ru/minec/activity/sections/bizinmprove/rankings/ (Дата обращения 21.06.2021). ["Russia in the international rankings", Official website of the Ministry of Economic Development of the Russian Federation, available at: http://old.economy.gov.ru/minec/activity/sections/bizinmprove/rankings/ (Accessed 21.06.2021)].

13. "Росстат рассчитал численность населения с доходами ниже прожиточного минимума в IV квартале 2020 года и за 2020 год в целом", Федеральная служба государственной статистики, доступно по адресу: https://rosstat.gov.ru/folder/313/document/119787 (Дата обращения 10.06.2021). ["Rosstat calculated the number of people with incomes below the subsistence minimum in the fourth quarter of 2020 and for 2020 as a whole", Federal State Statistics Service, available at: https://rosstat.gov.ru/folder/313/document/119787 (Accessed 10.06.2021)].

14. "Статистика внешнего сектора", Официальный сайт Банка России, доступно по адресу: https://cbr.ru/statistics/macro_itm/svs/ (Дата обращения 22.06.2021). [“External sector statistics", Official website of the Bank of Russia, available at: https://cbr.ru/statistics/macro_itm/svs/ (Accessed 22.06.2021)].

15. Сонин, К. (2020), "Российское правительство кризис застал врасплох, и первая реакция была замедленной”, Коронакризис - 2020: что будет и что делать? Сценарии развития и меры экономической политики, под ред. Рогова, К., Либеральная миссия, М. [Sonin, K. (2020), "The Russian government was caught by surprise by the crisis, and the first reaction was slow", Corona-crisis-2020: what will happen and what to do? Scenarios of development and measures of economic policy, in Rogov, K. (ed.), Liberal Mission, M.].

16. Указ Президента Российской Федерации от 07.05.2012 г. № 596 «О долгосрочной государственной экономической политике», доступно по адресу: http://kremlin.ru/acts/bank/35260 (Дата обращения 21.06.2021). [Decree of the President of the Russian Federation of 07.05.2012 No. 596 «On long-term state economic policy», available at: http://kremlin.ru/acts/bank/35260 (Accessed 21.06.2021)].

17. Цветков, В.А., Зоидов, К.Х., Янкаускас, К.С. и Кобил Ш. (2018), “Моделирование циклической динамики уровня бедности как социального показателя экономической безопасности России”, Экономика и управление, № 11 (157), с. 4-18. [Tsvetkov, V.A., Zoidov, K.Kh., Yankauskas, K.S. and Kobil Sh. (2018), "Modeling the cyclical dynamics of the 
poverty level as a social indicator of Russia's economic security", Economics and Management, no. 11 (157), pp. 4-18].

18. Цветков, В.А., Зоидов, К.Х., Янкаускас, К.С. и Кобил Ш.К. (2020), “Влияние экономических последствий пандемии коронавируса на уровень бедности и антикризисные меры национальных правительств", Россия в ХХІ веке: глобальные вызовы и перспективы развития. Пленарные доклады. Материаль Девятого Международного форума. 29-30 октября 2020 г., под ред. чл.-корр. РАН В.А. Цветкова, д.э.н., профессора Н.С. Зиядуллаева, к.ф.-м.н., доцента К.Х. Зоидова, ИПР РАН, М., 329 с., с. 250-263. [Tsvetkov, V.A., Zoidov, K.Kh., Yankauskas, K.S. and Kobil Sh.K. (2020), "The impact of the economic consequences of the coronavirus pandemic on the level of poverty and anti-crisis measures of national governments", Russia in XXI century: global challenges and prospects of development. Plenary lectures. Materials of the Ninth International Forum. 29-30 October's 2020, edited by Corresponding Member of the Russian Academy of Sciences V.A. Tsvetkov; Doctor of Sci. (Econ.), Professor Nabi S. Ziyadullayev, $\mathrm{PhD}$ in Physics and Mathematics, Associate Professor K.Kh. Zoidov, MEI RAS, M., 329 p., pp. 250-263].

19. “Экономическое развитие Евразийского экономического союза и государств-членов в 2019 году: аналитический доклад”, (2019), Евразийская экономическая комиссия, Международные рейтинги, Департамент макроэкономической политики Евразийской экономической комиссии, М., 107 с. ["Economic development of the Eurasian Economic Union and Member States in 2019: analytical report", (2019), The Eurasian Economic Commission, International ratings, Department of Macroeconomic Policy of the Eurasian Economic Commission, M., 107 p.].

20. Best Countries For Business 2019: Behind The Numbers, available at: https://www.forbes.com/sites/kurtbadenhausen/2018/12/19/best-countries-for-business-2019-behindthe-numbers (Accessed 21.06.2021).

21. Global Competitiveness Network: Frequently Asked Questions, available at: https://web.archive.org/web/20090326205427/http://www.weforum.org/en/initiatives/gcp/FAQs/index .htm (Accessed 21.06.2021).

22. India outlines $\$ 23$ billion stimulus to help poor hit by lockdown, available at: https://www.reuters.com/article/us-health-coronavirus-india-stimulus/india-outlines-23-billionstimulus-to-help-poor-hit-by-lockdown-idUSKBN21D0YK (Accessed 17.06.2021).

23. "Prime Minister outlines Canada's COVID-19 response". Prime Minister of Canada Justin Trudeau, available at: https://pm.gc.ca/en/news/news-releases/2020/03/11/prime-minister-outlinescanadas-covid-19-response (Accessed 17.06.2021).

24. Rowentree, B. (1901), Poverty - a study of Town Life, Macmillan, London.

25. Sala-i-Martin, Xavier and Elsa V. Artadi. (2004), "The Global Competitiveness Index", Global Competitiveness Report, Global Economic Forum 2004.

26. Spain unveils «unprecedented» 200 billion euros coronavirus package, available at: https://www.reuters.com/article/us-health-coronavirus-spain/spain-unveils-unprecedented-200-billioneuros-coronavirus-package-idUSKBN2141ZN (Accessed 11.06.2021).

27. "The Global Competitiveness Report. Special edition 2020", (2020), World Economic Forum, available at: https://www.weforum.org/reports/the-global-competitiveness-report-2020.

28. The Global wealth report 2020, available at: https://www.creditsuisse.com/media/assets/corporate/docs/about-us/research/publications/global-wealth-report-2020en.pdf (Accessed 04.06.2021).

29. Townsend, P. (1979), Poverty in the United Kingdom. A Survey of household resources and standards of living, N.Y.

30. "\$12.1 billion support for New Zealanders and business". The official website of the New Zealand Government, available at: https://www.beehive.govt.nz/release/121-billion-support-newzealanders-and-business (Accessed 11.06.2021). 


\title{
Об авторах
}

Зоидов Кобилжон Ходжиевич, к.ф.-м.н., доцент, заведующий лабораторией интеграции российской экономики в мировое хозяйство, Институт проблем рынка РАН, Москва. Москва.

Янкаускас Константин Стасисович, научный сотрудник, Институт проблем рынка РАН,

\begin{abstract}
About authors
Kobilzhon Kh. Zoidov, Candidate of Sci. (Phys.\&Math.), Associate Professor, Head of the Laboratory of the Russian Economy Integration into World Economy, Market Economy Institute of RAS, Moscow.
\end{abstract}

Konstantin S. Jankauskas, Research fellow, Market Economy Institute of RAS, Moscow. 